\title{
Temel Eğitim Kurumlarında Alınan Güvenlik Önlemlerinin Okul Kazalarına Etkisinin İncelenmesi
}

Investigation of The Effects of Security Measures Taken in Primary Education Institutions on School Accidents

\author{
Sümeyra GEVREK AKAR ${ }^{1}$, Aysel KÖKCÜ DOĞAN²
}

\begin{abstract}
ÖZ
$\mathrm{Bu}$ çalışma, temel eğitim kurumlarında alınan güvenlik önlemlerinin, okul kazalarına etkisini incelemek amacıyla yapılmıştır. Tanımlayıcı olarak yapılan araştırmanın örneklemini; Millî Eğitim Bakanlığı (MEB)'na bağlı İstanbul İl Milli Eğitim Müdürlüğü bünyesinde yer alan Güngören ilçesindeki 48 temel eğitim kurumunda görev yapan 568 yönetici ve çalışan oluşturmuştur. Veriler; araştırmacılar tarafından geliştirilen toplam 82 soruluk "Temel Eğitim Kurumlarında Alınan Güvenlik Önlemlerinin Okul Kazalarına Etkisinin İncelenmesi Anket Formu" ile toplanmıştır (Cronbach Alpha $=0,823)$. Araştırmaya katılan çalışanlar; okullarda meydana gelen kazaların büyük bir bölümünün $(\% 79,2)$ öğrencinin kendisinden kaynaklandığını, tüm okullarda ilk sırada $(\% 84,9)$ düşme kazalarının olduğunu, kazaların çoğunlukla okul binası dışında ve daha çok okul bahçesinde $(\% 72,9)$, bina içerisinde ise merdivenlerde $(\% 61,6)$ ve sinıflarda $(\% 58,8)$ meydana geldiğini belirtmişlerdir. Özel okullarda devlet okullarına göre daha fazla genel güvenlik önlemi alındığı belirlenmiştir. Bu sonuçlar, çocuk sağlığının korunması amacıyla okullarda yapılan fiziksel düzenlemelerin öğrencilerin yaş gruplarına uygun olması, MEB ile iş birliği sağlanarak tüm okullarda kazaları önlemeye yönelik standartlar oluşturulması, öğrenci ve çalışanlara yönelik bilinçlendirme çalışmalarının yapılması gerektiğini göstermektedir.
\end{abstract} Önlem

\begin{abstract}
This study was carried out to examine the security measures taken in basic educational institutions and their effect on school accidents. The sample of the research carried out as descriptive; consist of 568 managers and employees working in 48 basic education institutions in Güngören district of Istanbul Provincial Directorate of National Education, affiliated to Ministry of National Education (MEB). Data; A total of 82 questions used by the researchers were collected through the "Survey Form for the Investigation of the Effects of Security Measures Taken in Basic Education Institutions on School Accidents" (Cronbach Alpha = 0,823). Employees participating in the research expressed that; most of the accidents occurring in schools $(79.2 \%)$ originate from the student, there are fall accidents at the first place in all schools (84.9\%). They stated that accidents occurred on the stairs $(61.6 \%)$ and classrooms $(58.8 \%)$. It was determined that more general security measures are taken in private schools than public schools. These results indicate that physical arrangements made to protect children's health in schools should be suitable for children's age group; standards to prevent accidents in all school should be set in collaboration with MEB (Ministry of National Education) and activities should be done to raise awareness in students and employees.
\end{abstract}

Keywords: Accident, Child, Security, School, Measure

\footnotetext{
*Bu makale, yüksek lisans tezi 29 Kasım-2 Aralık 2017 tarihinde Antalya'da gerçekleştirilen 6. Ulusal 1. Uluslararası Pediatri Hemşireliği Kongresi'nde sözel bildiri olarak sunulmuştur.

${ }^{1}$ Uzm., Çocuk Sağlığı ve Hastalıkları Hemşireliği, sumgevrek@gmail.com, ORCID: 0000-0003-4269-6758

${ }^{2}$ Dr. Öğr. Üyesi, Çocuk Sağlığı ve Hastalıkları Hemşireliği, Medipol Üniversitesi Sağlık Bilimleri Fakültesi Hemşirelik Bölümü, akdogan@ medipol.edu.tr, ORCID: 0000-0003-3312-087X 


\section{GİRIŞ}

Ülkelerin refah düzeylerinin belirlenmesinde rolü olan sağlıklı bireylerin yetiştirilmesi, çocukluk döneminden itibaren sağlı̆̆ının bilincinde olan, sağlığını koruyabilen ve sağllk sorunu olduğunda fark eden bireyler ile mümkündür. ${ }^{1}$ Çocuklar günlerinin önemli bir kısmını eğitim kurumlarında veya eğitimle ilgili etkinliklerde geçirmektedir.

Okulların görevi; sadece çocukların akademik başarılarını sağlamak değil, aynı zamanda onların sağlıklı gelişimlerine yönelik diğer görevleri de yerine getirmektir. $\mathrm{Bu}$ görevlerden birisi de okul kazalarını önleyerek çocuklara, güvenli bir ortam hazırlamak ve onlara sağlıkların koruma bilincini verebilmektir. ${ }^{2}$

İnsan hayatında, fizyolojik ve psikolojik boyutu ile güvenlik önemli bir kavramdır. Temel insan gereksinimlerinden biri olan güvenlik, insan yaşamında önemli bir yere sahiptir. $\mathrm{Bu}$ bağlamda okul güvenliğinin temelini oluşturan konular, okulun emniyeti ve güvenliğinin sağlanması, okulun olası kriz ve afetlere karşı hazırlıklı olması, okulun fiziksel çevresinin düzenlenmesi ve güvenliği ile madde bağımlılı̆̆ına ilişkin düzenlemeler şeklinde sıralanabilir. ${ }^{3}$

Dünya Sağlık Örgütü (DSÖ) kazayı, bireyin iradesi dışında gelişen bir güç nedeni ile meydana gelen, ruhsal ve bedensel zedelenmelere yol açan olaylar olarak tanımlar. Kazalar beklenmeyen bir anda aniden ortaya çıkan zarar verici bir dış etken karşısında gelişir ve bireyin dikkat azlığ 1 ve ihmali ile oluşur. Kazalar çocukları fizyolojik, psikolojik ve sosyal yönden etkileyerek hastalık, sakatlık ve ölümlere neden olur.
Ayrıca aileye ve topluma maddi ve manevi yük getirir. ${ }^{4}$

İhmaller ve hatalı davranışların sonucunda oluşan kazalar, daha önceden alınacak önlemlerle engellenebilir olaylardır. $\mathrm{Bu}$ nedenle çocukluk çağı kazaları, üzerinde önemle durulması gereken bir konudur. ${ }^{5}$ Okul kazalarının nedenleri çevreye, ülkelere, mevsimlere ve ailelerin sosyoekonomik durumuna göre değişiklik göstermektedir. Kazalar ülkemizde 0-4 yaş grubu çocuk ölümleri arasında 5. sırada, 5-14 yaş grubunda ise birinci sırada yer almaktadır. ${ }^{6}$

Türkiye'de kazalarla ilgili en önemli kaynaklardan biri Sağlık Bakanlı̆ğ'nın Araştırma Planlama Koordinasyon Başkanlığı Sağlık İstatistik Yıllığı İçindeki ICD kod sistemine göre kaydedilen bilgilerdir. Buna göre 2014 yilında kazalar sonucu gelişen yaralanma, zehirlenme ve diş nedenlerden kaynaklı ölüm oran1 $\% 4,27^{`}$ dir. $\quad \mathrm{Bu}$ doğrultuda, sağlıklı nesiller ve sağlıklı bir gelecek oluşturabilmek amacı ile okul güvenliğinin sağlanması ve kazaların önlenmesi için koruyucu tedbirlerin kaza öncesi dönemde alınarak multidisipliner bir planlama ile toplumun geleceğini oluşturan çocukların korunması ve okullarda güvenliğin sağlanması önemlidir.?

Ülkemizde okullarda alınan güvenlik önlemlerinin kazalara etkisi konusunda yapılmış kapsamlı bir araştırmaya ulaşılamamıștır. Bu çalıșmayla; temel eğitim kurumlarında alınan güvenlik önlemlerinin, bu okullarda meydana gelebilecek kazalara etkisinin incelenmesi amaçlanmıştır.

\section{MATERYAL VE METOT}

\section{Araştırmanın Tipi}

Araştırma, temel eğitim kurumlarında alınan güvenlik önlemlerinin, bu okullarda meydana gelebilecek kazalara etkisinin incelenmesi amaciyla planlanan tanımlayıcı bir çalışmadır.

\section{Araştırmanın Yeri ve Zamanı}

Araştırma İstanbul İl Milli Eğitim Müdürlüğü'nden gerekli izinler alındıktan sonra, Güngören İlçesinde bulunan 48 temel eğitim kurumunda, 2016 Aralık-2017 Mart ayları arasında gerçekleştirilmiştir. 


\section{Evren ve Örneklemi}

Araştırmanın evrenini; İstanbul İl Milli Eğitim Müdürlüğü bünyesindeki Güngören İlçe Milli Eğitim Müdürlüğü'ne bağl1 25 devlet okulu (1 anaokulu, 11 ilkokul, 13 ortaokul) ve 23 özel okul (13 anaokulu, 5 ilkokul, 5 ortaokul) olmak üzere toplam 48 temel eğitim kurumu oluşturmuştur. Örneklemini ise okulun çeşitli kadrolarında yer alan 1281 görevli personelden, araştırmaya katılmaya gönüllü 563 yönetici, öğretmen, hemşire, hizmetli personel ve güvenlik görevlisi oluşturmuştur.

\section{Veri Toplama Araçları}

Araştırmanın verileri; araştırmacılar tarafından literatür bilgileri doğrultusunda hazırlanan ve uzman görüşlerine göre tekrar düzenlenen "Temel Eğitim Kurumlarında Alınan Güvenlik Önlemlerinin Okul Kazalarına Etkisinin İncelenmesi Formu" ile toplanmıştır. Form, tanıtıcı bilgiler (5 soru), kazalara yönelik bireysel görüşler (13 soru) ve okul güvenliğine ilişkin görüşler bölümü; kurum içi: genel bilgi (29 soru), bahçe (5 soru), merdiven/koridor (5 soru), sinif (5 soru), spor salonu (2 soru), yemekhane/kantin (5 soru), tuvalet (3 soru), güvenlik (5 soru); kurum dış1; çevre (5 soru) olmak üzere toplam 3 bölüm ve 82 sorudan oluşmuştur. Çalışanların maddelere 'evet, hayır, bilmiyorum", olarak yanıt vermeleri istenmiş ve güvenlik önlemi maddelerine verilen yanitlar evet (2), hayır (0), bilmiyorum (1) olarak puanlanmıştır.

\section{Araştırmanın Uygulanması}

Araştırma İstanbul İl Milli Eğitim Müdürlüğü'nden gerekli izinler alındıktan sonra okul müdürleri ile telefonla görüşülerek araştırma öncesi anket formları hakkında bilgi verilmiş, ayrıca uygulamaya başlamadan önce anket sorularının anlaşılırlığını değerlendirmek amacı ile bir devlet ve bir özel okuldan rastgele seçilen 15 'er kişilik iki grup çalışan ile ön uygulama yapılmıştır. Anlaşılmayan sorulara yönelik yeniden düzenlemeler yapılarak ankete son şekli verilmiştir. Veriler araştırmaya katılmaya gönüllü çalışanlara gerekli açıklamalar yapıldıktan ve onam alındiktan sonra toplanmıştır.

\section{Verilerin Değerlendirilmesi}

Araştırma verileri lisanslı IBM SPSS (Statistical Package for Social Sciences) for Windows 22.0 programı ile analiz edilmiştir. Verilerin analizinde tanımlayıcı istatistiksel yöntemler olarak sayı, ortalama, yüzde, standart sapma, Post Hoc Testi, T Testi, ANOVA Testi kullanılmıştır.

\section{Araştırmanın Değişkenleri}

Okullarda meydana gelen kazalar ve güvenlik önlemleri bağımlı değişkenlerdir. Yaş, eğitim durumu, çalışma yılı ve kazalara yönelik eğitim alma durumu ise bağımsız değişkenlerdir.

\section{Araştırmanın Etik Yönü}

Araştırma için 08.09.2016 tarihinde İstanbul Medipol Üniversitesi Girişimsel Olmayan Klinik Araştırmalar Etik Kurulu'ndan 10840098-604.01.01-E.15930 sayılı etik kurul onay1, 28/10/2016 tarihinde İstanbul İl Milli Eğitim Müdürlüğü'nden 59090411-44-E.12110986 sayılı araştırma izni alınmıştır. Veri toplamaya başlamadan önce araştırmaya katılanlara araştırma hakkında bilgi verilerek 'Gönüllü Oluru' ve ' 'Gönüllülük', ilkesine, araştırmaya katılma konusunda özgür oldukları belirtilerek 'Ö̈zerkliğe Saygı', ilkesine, araştırmaya katılanların bilgilerinin gizli tutulacağ belirtilerek 'Gizlilik ve Gizliliğin Korunması" ilkesine bağlı kalınarak araştırmaya katılanların kimlik bilgileri kullanılmadan araştırma yürütülmüştür.

\section{Araştırmanın Sınırlılığı}

Araştırma, Güngören İlçe Milli Eğitim Müdürlüğü sınırları içindeki temel eğitim kurumları arasında yer alan devlet ve özel okulların çalışmaya katılmaya gönüllü yönetici ve çalışanları ile sınırlı olup, veriler kişisel bilgiye dayalıdır. 


\section{BULGULAR VE TARTIŞMA}

Araştırmaya katılanların \% 71,5'inin devlet okulunda, \%28,5'inin ise özel okulda çalıştıkları, \%79'unun öğretmen, \%9,5'inin hizmetli, \%7,2'sinin yönetici, \%2,1'inin güvenlik görevlisi, \%1,6'sının hemşire, $\% 0,5$ 'nin ise diğer çalışanlar grubunda yer aldığı belirlenmiştir.

Çalışanların \%3,9'unun ilkokul, $\% 4,9$ 'unun ortaokul, \%3,7'sinin lise, $\% 81,3$ 'ünün üniversite, $\% 6,2$ 'sinin ise yüksek lisans mezunu oldukları saptanmıştır (Tablo1).

Tablo 1. Okul Çalışanlarının Tanımlayı̀ı Özelliklerine Göre Dağılımı

\begin{tabular}{llrr}
\hline & & n & \% \\
\hline Okul & Devlet Okulu & 406 & 71,5 \\
Türü & Özel Okul & 162 & 28,5 \\
\hline & Öğretmen & 449 & 79,0 \\
& Hizmetli & 54 & 9,5 \\
& Yönetici & 41 & 7,2 \\
Görev & Güvenlik & 12 & 2,1 \\
& Görevlisi & & \\
& Hemşire ve & 12 & 2,1 \\
& Diğer & 22 & 3,9 \\
Eğitim & Ilkokul & 28 & 4,9 \\
Düzeyi & Ortaokul & 21 & 3,7 \\
& Lise & 462 & 81,3 \\
& Üniversite & 35 & 6,2 \\
& Yüksek Lisans & 568 & 100,0 \\
\hline
\end{tabular}

Çalışan görüşleri doğrultusunda okul türüne göre kaza tipleri incelendiğinde; okullarda ilk sırada düşmelerin (devlet okulları \%86,5; özel okullar \%80,9), ikinci sırada ise çarpmaların (devlet okulları \%76,4; özel okullar \%72,2) meydana geldiği belirlenmiştir (Tablo 2).

Okul türüne göre en çok kaza geçirilen yerlerin devlet okullarında sirasıyla; okul bahçesinde $(\% 74,9)$, merdivenlerde $(\% 65,3)$, siniflarda $(\% 59,9)$ ve koridorlarda $(\% 58,6)$, özel okullarda ise okul bahçesinde $(\% 67,9)$, siniflarda $(\% 56,2)$, koridorlarda $(\% 56,2)$ ve merdivenlerde $(\% 52,5)$ görüldüğü okul çalışanları tarafından belirtilmiştir (Tablo 3).
Tablo 2. Okul Türüne Göre Kaza Tipleri

\begin{tabular}{|c|c|c|c|c|c|c|}
\hline \multirow{4}{*}{ Düşme } & \multirow{4}{*}{$\begin{array}{l}\text { Evet } \\
\text { Hayır }\end{array}$} & \multicolumn{2}{|c|}{$\begin{array}{l}\text { Devlet } \\
\text { Okulu }\end{array}$} & \multicolumn{2}{|c|}{ Özel Okul } & \multirow[t]{2}{*}{$\mathbf{p}$} \\
\hline & & $\mathbf{n}$ & $\%$ & $\mathbf{n}$ & $\%$ & \\
\hline & & 351 & $\% 86,5$ & 131 & $\% 80,9$ & $X^{2}=2,815$ \\
\hline & & 55 & $\% 13,5$ & 31 & $\% 19,1$ & $\mathrm{p}=0,063$ \\
\hline \multirow{2}{*}{$\begin{array}{l}\text { Yüksekten } \\
\text { Düşme }\end{array}$} & Evet & 36 & $\% 8,9$ & 13 & $\% 8,0$ & $X^{2}=0,104$ \\
\hline & Hayır & 370 & $\% 91,1$ & 149 & $\% 92,0$ & \\
\hline \multirow{2}{*}{$\begin{array}{l}\text { Burun } \\
\text { Kanaması }\end{array}$} & Evet & 90 & $\% 22,2$ & 35 & $\% 21,6$ & $X^{2}=0,021$ \\
\hline & Hayır & 316 & $\% 77,8$ & 127 & $\% 78,4$ & $\mathrm{p}=0,490$ \\
\hline \multirow{2}{*}{ Çarpma } & Evet & 310 & $\% 76,4$ & 117 & $\% 72,2$ & $\mathrm{X}^{2}=1$ \\
\hline & Hayır & 96 & $\% 23,6$ & 45 & $\% 27,8$ & $\mathrm{p}=0$ \\
\hline \multirow{2}{*}{ Kayma } & Evet & 119 & $\% 29,3$ & 65 & $\% 40,1$ & $X^{2}=6,182$ \\
\hline & Hayır & 287 & $\% 70,7$ & 97 & $\% 59,9$ & $\mathrm{p}=0,009$ \\
\hline \multirow{2}{*}{$\begin{array}{l}\text { Kafa } \\
\text { Travması }\end{array}$} & Evet & 22 & $\% 5,4$ & 2 & $\% 1,2$ & $X^{2}=$ \\
\hline & Hayır & 384 & $\% 94,6$ & 160 & $\% 98,8$ & $\mathrm{p}=0,016$ \\
\hline \multirow{2}{*}{ Kesilme } & Evet & 48 & $\% 11,8$ & 17 & $\% 10,5$ & $X^{2}=0,202$ \\
\hline & Hayır & 358 & $\% 88,2$ & 145 & $\% 89,5$ & $\mathrm{p}=0,387$ \\
\hline \multirow{2}{*}{ Vurma } & Evet & 238 & $\% 58,6$ & 92 & $\% 56,8$ & \\
\hline & Hayır & 168 & $\% 41,4$ & 70 & $\% 43,2$ & $\mathrm{p}=0,379$ \\
\hline \multirow{2}{*}{$\begin{array}{l}\text { Kırık } \\
\text { Çıkık } \\
\end{array}$} & Evet & 99 & $\% 24,4$ & 46 & $\% 28,4$ & $\mathrm{X}^{2}=0,980$ \\
\hline & Hayır & 307 & $\% 75,6$ & 116 & $\% 71,6$ & $\mathrm{p}=0,188$ \\
\hline \multirow{2}{*}{$\begin{array}{l}\text { Elektrik } \\
\text { Çarpması }\end{array}$} & Evet & 8 & $\% 2,0$ & 0 & $\% 0,0$ & $X^{2}=3,238$ \\
\hline & Hayır & 398 & $\% 98,0$ & 162 & $\% 100,0$ & $\mathrm{p}=0,067$ \\
\hline \multirow{2}{*}{ Diğer } & Evet & 20 & $\% 4,9$ & 12 & $\% 7,4$ & $\mathrm{X}^{2}=1,341$ \\
\hline & Hayır & 386 & $\% 95,1$ & 150 & $\% 92,6$ & $\mathrm{p}=0,169$ \\
\hline
\end{tabular}

* Post Hoc Testi

Tablo 3. Okul Türüne Göre Kaza Geçirilen Yerler

\begin{tabular}{|c|c|c|c|c|c|c|}
\hline & & \multicolumn{2}{|c|}{$\begin{array}{l}\text { Devlet } \\
\text { Okulu }\end{array}$} & \multicolumn{2}{|c|}{ Özel Okul } & \multirow[t]{2}{*}{$\mathbf{p}$} \\
\hline & & $\mathbf{n}$ & $\%$ & $\mathbf{n}$ & $\%$ & \\
\hline \multirow{2}{*}{ Sinıf } & Evet & 243 & $\% 59,9$ & 91 & $\% 56,2$ & $X^{2}=0,647$ \\
\hline & Hayır & 163 & $\% 40,1$ & 71 & $\% 43,8$ & $\mathrm{p}=0,239$ \\
\hline \multirow{2}{*}{$\begin{array}{l}\text { Okul } \\
\text { Bahçesi }\end{array}$} & Evet & 304 & $\% 74,9$ & 110 & $\% 67,9$ & $X^{2}=2,851$ \\
\hline & Hayır & 102 & $\% 25,1$ & 52 & $\% 32,1$ & $\mathrm{p}=0,058$ \\
\hline \multirow{2}{*}{ Merdiven } & Evet & 265 & $\% 65,3$ & 85 & $\% 52,5$ & $X^{2}=8,024$ \\
\hline & Hayır & 141 & $\% 34,7$ & 77 & $\% 47,5$ & $\mathrm{p}=0,003$ \\
\hline \multirow{2}{*}{ Koridor } & Evet & 238 & $\% 58,6$ & 91 & $\% 56,2$ & $X^{2}=0,285$ \\
\hline & Hayır & 168 & $\% 41,4$ & 71 & $\% 43,8$ & $\mathrm{p}=0,330$ \\
\hline \multirow{2}{*}{ Kantin } & Evet & 52 & $\% 12,8$ & 20 & $\% 12,3$ & $X^{2}=0,022$ \\
\hline & Hayır & 354 & $\% 87,2$ & 142 & $\% 87,7$ & $\mathrm{p}=0,502$ \\
\hline \multirow{2}{*}{ Tuvalet } & Evet & 66 & $\% 16,3$ & 21 & $\% 13,0$ & $X^{2}=0,968$ \\
\hline & Hayır & 340 & $\% 83,7$ & 141 & $\% 87,0$ & $\mathrm{p}=0,197$ \\
\hline \multirow{2}{*}{ Spor Salonu } & Evet & 34 & $\% 8,4$ & 18 & $\% 11,1$ & $X^{2}=1,04$ \\
\hline & Hayır & 372 & $\% 91,6$ & 144 & $\% 88,9$ & $\mathrm{p}=0,194$ \\
\hline \multirow{2}{*}{ Laboratuvar } & Evet & 8 & $\% 2,0$ & 1 & $\% 0,6$ & $X^{2}=1,360$ \\
\hline & Hayır & 398 & $\% 98,0$ & 161 & $\% 99,4$ & $\mathrm{p}=0,221$ \\
\hline \multirow{2}{*}{ Diğer } & Evet & 7 & $\% 1,7$ & 1 & $\% 0,6$ & $X^{2}=1,022$ \\
\hline & Hayır & 399 & $\% 98,3$ & 161 & $\% 99,4$ & $\mathrm{p}=0,284$ \\
\hline
\end{tabular}

* Post Hoc Testi 
Araştırma grubunda yer alan çalışanlar kazaların öncelikle çocuğun kendisinden (devlet okullarında \%80, özel okullarda $\% 77,2$ ) daha sonra başka çocuklardan (devlet okullarında \%48,3, özel okullarda \%50) kaynaklandığını belirtmişlerdir (Tablo 4).

Tablo 4. Okul Türüne Göre Kaza Nedenleri

\begin{tabular}{|c|c|c|c|c|c|c|}
\hline \multirow{4}{*}{$\begin{array}{l}\text { Çocuğun } \\
\text { Kendisinden } \\
\text { Kaynaklı } \\
\end{array}$} & \multirow{4}{*}{$\begin{array}{l}\text { Evet } \\
\text { Hayır }\end{array}$} & \multicolumn{2}{|c|}{$\begin{array}{l}\text { Devlet } \\
\text { Okulu }\end{array}$} & \multicolumn{2}{|c|}{ Özel Okul } & \multirow[t]{2}{*}{$\mathbf{p}$} \\
\hline & & $\mathbf{n}$ & $\%$ & $\mathbf{n}$ & $\%$ & \\
\hline & & 325 & $\% 80,0$ & 125 & $\% 77,2$ & \multirow{2}{*}{$\begin{aligned} X^{2} & =0,587 \\
p & =0,256\end{aligned}$} \\
\hline & & 81 & $\% 20,0$ & 37 & $\% 22,8$ & \\
\hline \multirow{2}{*}{$\begin{array}{l}\text { Başka } \\
\text { Çocuktan } \\
\text { Kaynaklı } \\
\end{array}$} & Evet & 196 & $\% 48,3$ & 81 & $\% 50$ & \multirow{2}{*}{$\begin{aligned} X^{2} & =0,138 \\
p & =0,390\end{aligned}$} \\
\hline & Hayır & 210 & $\% 51,7$ & 81 & $\% 50$ & \\
\hline $\begin{array}{l}\text { Okuldaki } \\
\text { Kuralsızlık } \\
\text { ve }\end{array}$ & Evet & 68 & $\% 16,7$ & 23 & $\% 14,2$ & \multirow{2}{*}{$\begin{aligned} X^{2} & =0,560 \\
p & =0,270\end{aligned}$} \\
\hline $\begin{array}{l}\text { Kontrolsüzlü } \\
\text { kten } \\
\text { Kaynaklı } \\
\end{array}$ & Hayır & 338 & $\% 83,3$ & 139 & $\% 85,8$ & \\
\hline \multirow{2}{*}{$\begin{array}{l}\text { Okuldaki } \\
\text { Çevresel } \\
\text { Faktörlerin } \\
\text { Yetersizliğin } \\
\text { den } \\
\text { Kaynaklı } \\
\end{array}$} & Evet & 80 & $\% 19,7$ & 36 & $\% 22,2$ & \multirow{2}{*}{$\begin{array}{r}\mathrm{X}^{2}=0,452 \\
\mathrm{p}=0,287\end{array}$} \\
\hline & Hayır & 326 & $\% 80,3$ & 126 & $\% 77,8$ & \\
\hline \multirow{2}{*}{ Diğer } & Evet & 14 & $\% 3,4$ & 5 & $\% 3,1$ & \multirow{2}{*}{$\begin{aligned} X^{2} & =0,047 \\
p & =0,531\end{aligned}$} \\
\hline & Hayır & 392 & $\% 96,6$ & 157 & $\% 96,9$ & \\
\hline
\end{tabular}

* Post Hoc Testi

Çalışan görüşlerine göre okullarda alınan güvenlik önlemleri ile yaşanan kaza türleri karşılaştırıldığında (Şekil 1); okullarda genel güvenlik önlemlerinin alındığı alanlarda, düşme, burun kanaması, kayma, kafa travması, kesilme, vurma, kırık-çıkık, elektrik çarpmasının daha az görüldüğü ve genel güvenlik önlemleri puan ortalamaları ile kaza türleri puan ortalamaları arasındaki farkın istatistiksel olarak anlamlı olduğu saptanmıştır $(\mathrm{p}<0,05)$.

Araştırma kapsamındaki okulların bahçesinde alınan güvenlik önlemleri sayesinde düşme, burun kanaması, çarpma, kayma, vurma, kırık-çıkık kazalarının daha az meydana geldiği, okul bahçesine yönelik alınan güvenlik önlemleri puan ortalamaları ile kaza puan ortalamaları arasındaki farkın istatistiksel olarak anlamlı olduğu belirlenmiştir $(\mathrm{p}<0,05)$.
Örneklem grubunda yer alan okulların merdiven ve koridorlarında düşme, kayma, kesilme, vurma şeklindeki kazaların görülme sıklığının daha düşük olduğu, bu kazalar ile merdiven ve koridorlara yönelik güvenlik önlemleri puanları arasında anlamlı fark olduğu saptanmıştır $(\mathrm{p}<0,05)$.

Araştırma kapsamında yer alan okulların sınıflarında düşme, burun kanaması, çarpma, kesilme, vurma vakalarının daha az görüldüğü, sınıflara yönelik güvenlik önlemleri ile kaza çeşitleri arasındaki farkın istatistiksel olarak anlamlı olduğu tespit edilmiştir $(p<0,05)$.

Okulların spor salonlarında alınan güvenlik önlemleri ile yüksekten düşme, çarpma, kafa travması, kesilme, elektrik çarpması puan ortalamaları arasındaki fark istatistiksel anlamlı olup $(p<0,05)$, spor salonlarında bu kazaların görülme sayısı düşük bulunmuştur.

Örneklem grubunda yer alan okulların yemekhane ve kantinlerinde alınan güvenlik önlemleri ile yüksekten düşme, burun kanaması, çarpma, kesilme, vurma, kırıkçıkık şeklindeki kazaların puan ortalamaları arasındaki fark istatistiksel olarak anlamlıdır $(p<0,05)$.

Okulların tuvaletlerinde alınan güvenlik önlemleri ile burun kanaması, kayma, kesilme, vurma, kırık çıkık, elektrik çarpması kazaları puan ortalamaları arasında istatistiksel anlamlı fark tespit edilmiştir $(\mathrm{p}<0,05)$.

Araştırma kapsamında bulunan okulların yakın çevredeki risklere yönelik farkındalık puan ortalamaları ile burun kanaması, kafa travması, kesilme, vurma, elektrik çarpması puan ortalamaları arasında istatistiksel olarak anlamlı fark saptanmıştır $(\mathrm{p}<0,05)$. Okulların yakın çevredeki risklere yönelik farkındalık puan ortalamaları arttıkça kaza görülme oranlarının düştüğü belirlenmiştir. 
Örneklem grubunda bulunan okullarda kazaları önlemeye yönelik alınan tedbirlerin puan ortalamaları ile yüksekten düşme, kayma, kafa travması, kesilme, elektrik çarpması puan ortalamaları arasındaki fark istatistiksel olarak anlamlı bulunmuştur $(\mathrm{p}<0,05)$, (Şekil 1).

Son yıllarda ülkemizde önem kazanan "okul kazaları" ile ilgili kapsamlı çalışmalar yapılmaya başlanmakla birlikte, konuyla ilgili yeterli veri bulunmamaktadır. Bunun nedeni yaşanan kazaların raporlarını bildirirken aksaklıkların olması, okul çalışanlarının konuya yeterince önem vermemesi, araştırma sonuçlarından çekinmesi veya iş yüklerinin fazla olması olabilir. Ülkemizde de bütün kaza ve yaralanmaların kayıt edildiği bir sistem henüz oluşturulmamıştır. Bu nedenle okul kazalarına karşı alınan güvenlik önlemlerine ilişkin spesifik standart planlanması mümkün değildir. Türkiye İstatistik Kurumu (TÜİK) verileri daha çok trafik ve ev kazalarına yöneliktir. Yurt içindeki literatür incelendiğinde okul kazalarının epidemiyolojisini belirlemeye yönelik yapılan çalışmalar vardır. Fakat okullarda alınan güvenlik önlemlerinin okul kazalarına etkisi incelenmemiştir.

\begin{tabular}{|c|c|c|c|c|c|c|c|c|c|c|}
\hline $\begin{array}{l}\text { Demografik } \\
\text { Ozellikler }\end{array}$ & n & $\begin{array}{c}\text { Genel } \\
\text { Güvenlik } \\
\text { Önlemleri }\end{array}$ & $\begin{array}{c}\text { Okul } \\
\text { Bahçesine } \\
\text { Yönelik } \\
\text { Güvenlik } \\
\text { Önlemleri }\end{array}$ & $\begin{array}{c}\text { Merdiven Ve } \\
\text { Koridorlara } \\
\text { Yönelik } \\
\text { Güvenlik } \\
\text { Önlemleri }\end{array}$ & $\begin{array}{c}\text { Sinuflara } \\
\text { Yönelik } \\
\text { Güvenlik } \\
\text { Önlemleri }\end{array}$ & $\begin{array}{c}\text { Spor } \\
\text { Salonuna } \\
\text { Yönelik } \\
\text { Güvenlik } \\
\text { Önlemleri }\end{array}$ & $\begin{array}{l}\text { Yemekhane } \\
\text { Ve Kantine } \\
\text { Yönelik } \\
\text { Güvenlik } \\
\text { Önlemleri }\end{array}$ & $\begin{array}{c}\text { Tuvaletlere } \\
\text { Yönelik } \\
\text { Güvenlik } \\
\text { Önlemleri }\end{array}$ & $\begin{array}{c}\text { Yakan } \\
\text { Cevredeki } \\
\text { Risklere } \\
\text { Yönelik } \\
\text { Farkandallk }\end{array}$ & $\begin{array}{c}\text { Kazalan } \\
\text { Önlemeye } \\
\text { Yönelik } \\
\text { Tedbirler }\end{array}$ \\
\hline Dügme & & OrttsS & OnttsS & OrteSS & OntesS & OrttSS & OrttsS & OnteSS & OnteSS & OrtesS \\
\hline Evet & 482 & $43,180 \pm 7,621$ & $5,240 \pm 2,097$ & $7,110 \pm 1,994$ & $6,280 \pm 1,607$ & $2,540 \pm 1,244$ & $8,350 \pm 2,076$ & $5,540 \pm 1,142$ & $7,530 \pm 2,149$ & $6,260 \pm 2,023$ \\
\hline Hayzr & 86 & $45,440 \pm 5,557$ & $6,130 \pm 2,163$ & $7,900 \pm 1,503$ & $6,910 \pm 1,411$ & $2,720 \pm 1,470$ & $8,830 \pm 1,855$ & $5,620 \pm 1,031$ & $7,470 \pm 2,734$ & $6,210 \pm 1,977$ \\
\hline$t=$ & & $-2,624$ & $-3,597$ & $-3,471$ & $-3,369$ & $-0,935$ & $-1,968$ & $-0,567$ & 0,259 & 0,221 \\
\hline$p=$ & & 0,001 & 0,000 & 0,000 & 0,001 & 0,413 & 0,035 & 0,571 & 0,827 & 0,825 \\
\hline $\begin{array}{l}\text { Yüksekten } \\
\text { Düşme }\end{array}$ & & OrttSS & OrttSS & OrttSS & OrttsS & OrttSS & OrttsS & Ortess & OrteSS & OrteSS \\
\hline Evet & 49 & $41,650 \pm 8,599$ & $5,390 \pm 1,455$ & $7,570 \pm 1,242$ & $6,490 \pm 1,894$ & $2,070 \pm 1,311$ & $8,900 \pm 1,517$ & $5,310 \pm 1,584$ & $7,060 \pm 2,313$ & $5,240 \pm 1,535$ \\
\hline Hayr & 519 & $43,700 \pm 7,246$ & $5,370 \pm 2,183$ & $7,200 \pm 1,998$ & $6,370 \pm 1,564$ & $2,600 \pm 1,263$ & $8,380 \pm 2,088$ & $5,580 \pm 1,072$ & $7,570 \pm 2,236$ & $6,350 \pm 2,030$ \\
\hline$t=$ & & $-1,861$ & 0,044 & 1,283 & 0,511 & $-2,227$ & 1,689 & $-1,607$ & $-1,508$ & $-3,707$ \\
\hline$p=$ & & 0,112 & 0,952 & 0,063 & 0,664 & 0,027 & 0,032 & 0,248 & 0,132 & 0,000 \\
\hline $\begin{array}{l}\text { Burun } \\
\text { Kanaması }\end{array}$ & & OrttSS & OrttSS & OrtteSS & OrttsS & OrttSS & OrttSS & OrttSS & OrttSS & OrttsS \\
\hline Evet & 125 & $40,590 \pm 7,779$ & $4,700 \pm 2,068$ & $6,980 \pm 1,760$ & $5,660 \pm 1,931$ & $2,450 \pm 0,830$ & $7,830 \pm 2,372$ & $5,220 \pm 1,317$ & $6,180 \pm 2,718$ & $6,420 \pm 1,756$ \\
\hline Hayry & 443 & $44,350 \pm 7,063$ & $5,560 \pm 2,111$ & $7,300 \pm 1,993$ & $6,580 \pm 1,422$ & $2,590 \pm 1,359$ & $8,590 \pm 1,919$ & $5,650 \pm 1,048$ & $7,900 \pm 1,933$ & $6,210 \pm 2,081$ \\
\hline$t=$ & & $-5,141$ & $-4,043$ & $-1,606$ & $-5,910$ & $-0,865$ & $-3,711$ & $-3,834$ & $-8,007$ & 1,021 \\
\hline$p=$ & & 0,000 & 0,000 & 0,109 & 0,000 & 0,251 & 0,000 & 0,001 & 0,000 & 0,308 \\
\hline Carpma & & Ortess & Ontess & OnteSS & Ontess & OrttsS & Ontess & Ontess & Ortess & Ortess \\
\hline Evet & 427 & $43,430 \pm 7,231$ & $5,190 \pm 2,146$ & $7,140 \pm 1,714$ & $6,300 \pm 1,674$ & $2,410 \pm 1,202$ & $8,330 \pm 2,148$ & $5,560 \pm 1,098$ & $7,480 \pm 2,140$ & $6,230 \pm 1,879$ \\
\hline Hayrz & 141 & $43,820 \pm 7,858$ & $5,950 \pm 1,976$ & $7,500 \pm 2,512$ & $6,620 \pm 1,296$ & $3,000 \pm 1,376$ & $8,720 \pm 1,687$ & $5,550=1,210$ & $7,660 \pm 2,541$ & $6,310 \pm 2,385$ \\
\hline$t=$ & & $-0,536$ & $-3,742$ & $-1,925$ & $-2,117$ & $-3,989$ & $-1,992$ & 0,082 & $-0,834$ & $-0,398$ \\
\hline$p=$ & & 0,592 & 0,000 & 0,112 & 0,017 & 0,000 & 0,025 & 0,935 & 0,445 & 0,724 \\
\hline Kayma & & OrteSS & OrteSS & OnteSS & OrteSS & OrteSS & OrteSS & OnteSS & Ortess & OrteSS \\
\hline Evet & 184 & $42,580 \pm 7,763$ & $4,950 \pm 2,336$ & $6,880 \pm 1,596$ & $6,270 \pm 1,526$ & $2,600 \pm 1,370$ & $8,180 \pm 2,323$ & $5,330 \pm 1,273$ & $7,310 \pm 2,134$ & $5,950 \pm 1,674$ \\
\hline Hayrx & 384 & $43,980 \pm 7,165$ & $5,580 \pm 1,995$ & $7,400 \pm 2,074$ & $6,430 \pm 1,624$ & $2,540 \pm 1,233$ & $8,540 \pm 1,896$ & $5,660 \pm 1,033$ & $7,620 \pm 2,292$ & $6,400 \pm 2,146$ \\
\hline$t=$ & & $-2,129$ & $-3,313$ & $-3,036$ & $-1,162$ & 0,421 & $-1,947$ & $-3,271$ & $-1,568$ & $-2,488$ \\
\hline$p=$ & & 0,039 & 0,002 & 0,001 & 0,246 & 0,674 & 0,071 & 0,003 & 0,117 & 0,007 \\
\hline
\end{tabular}

Şekil 1. Güvenlik Önlemlerinin Geçirilen Kaza Türlerine Göre Karşılaştırılması

Araștırmaya katılan okullardaki çalışanların büyük bir bölümü $(\% 79,2)$ kazaların çocuğun kendisinden kaynaklandığını düşünmektedirler. Yertutan ve Erkal'ın yaptığı çalışmada, çocuğun kendisinden kaynaklı kaza meydana gelme oranının yüksek olması çalışmamızla paralellik göstermektedir. Laflamme ve arkadaşlarının geliştirdiği güvenlik modeline göre ise çocuklar kazaya tek başına veya birlikte neden olmaktadır. ${ }^{7}$
TÜİK 2014 verilerine göre kaza sıklığı ve şiddeti ise okuldan okula değişmekte, kazaların yarısının çocuğun kendi davranışlarından, dörtte birinin başka bir çocuk tarafından, dörtte birinin ise çevreden kaynaklandığ 1 belirtilmektedir. ${ }^{8} \quad 2017$ verilerine göre ise 1-17 yaş grubu en fazla çocuk ölümlerinin dişsal yaralanma ve zehirlenmelerden kaynaklandığı açıklanmıştır. ${ }^{9}$ 
Araştırma genelindeki tüm okullarda çocukların geçirdikleri kaza tiplerinin ilk sırasında düşme yer almaktadır. Erarslan'ın çalışmasında da çocukların uğradıkları kazaların oluş şeklinin ilk sırasında düşme bulunmaktadır. ${ }^{10}$ Gür, Di Scala, Gallagher, Yertutan okul yaralanmalarına neden olan faktörlerin düşme, çarpma ve çelme takma olduğunu belirtmişlerdir. ${ }^{11}$ Willims ve Latif ise okullarda düşmelerin yaygın olduğunu belirtmiştir. ${ }^{12} \mathrm{Bu}$ sonuçlar, araştırmamızdan elde edilen sonuçları desteklemektedir.

Vosskuhler, Miller ve arkadaşlarına göre dünyadaki birçok ülkede gelişmişlik ve kalkınmışlık düzeyi gözetilmeksizin okul ile ilgili; kayma, düşme, trafik kazaları, şiddete bağlı yaralanmalar, zorbalık, alkol ve madde kullanımı gibi nedenlerle çok sayıda çocuk yaralanmakta, zarar görmekte ve hayatını kaybetmektedir. ${ }^{13}$

UNICEF'in yaptığ 1 bir araştırmada düşme, 0-6 yaş grubundaki çocuklarda en çok rastlanan kaza tipidir. Düşmeler daha çok koşarken, merdivenden, kaygan ve uygun olmayan zeminden, ziplarken meydana gelmektedir. Çocukların bilinçsizce davranması, oyun alanlarını kontrolsüz kullanması (salıncak vb.), yüksek kapı eşikleri, yetersiz aydınlatılmış mekânlar, ani ve hızlı hareketler, koridorda düşmeler, mobilyaların üzerine çıkmalar düşmelere neden olan etkenlerdir. ${ }^{14}$

Pişkin ve arkadaşlarının araştırmalarına göre ise, çocukların yaşadıkları kafa travmaları ve kayma, okullarda daha fazla karşılaştıkları yaralanmalardır. ${ }^{15}$

\begin{tabular}{|c|c|c|c|c|c|c|c|c|c|c|}
\hline $\begin{array}{l}\text { Demografik } \\
\text { Özellikler }\end{array}$ & $n$ & $\begin{array}{c}\text { Genel } \\
\text { Güvenlik } \\
\text { Önlemleri }\end{array}$ & $\begin{array}{c}\text { Okul } \\
\text { Bahçeaine } \\
\text { Yönelik } \\
\text { Güvenlik } \\
\text { Ö̈nlemleri }\end{array}$ & $\begin{array}{c}\text { Merdiven Ve } \\
\text { Koridorlara } \\
\text { Yönelik } \\
\text { Güvenlik } \\
\text { Önlemleri } \\
\end{array}$ & $\begin{array}{c}\text { Smuflara } \\
\text { Yönelik } \\
\text { Güvenlik } \\
\text { Önlemleri } \\
\end{array}$ & $\begin{array}{c}\text { Spor } \\
\text { Salonuna } \\
\text { Yönelik } \\
\text { Güvenlik } \\
\text { Önlemleri }\end{array}$ & $\begin{array}{c}\text { Yemekhane } \\
\text { Ve Kantine } \\
\text { Yönelik } \\
\text { Güvenlik } \\
\text { Önlemleri }\end{array}$ & $\begin{array}{c}\text { Tuvaletlere } \\
\text { Yönelik } \\
\text { Güvenlik } \\
\text { Önlemleri } \\
\end{array}$ & $\begin{array}{c}\text { Yakan } \\
\text { Cevredeki } \\
\text { Risklere } \\
\text { Yönelik } \\
\text { Farkandallk } \\
\end{array}$ & $\begin{array}{c}\text { Kazalan } \\
\text { Önlemeye } \\
\text { Yönelik } \\
\text { Tedbirler }\end{array}$ \\
\hline $\begin{array}{l}\text { Kafa } \\
\text { Travmasi }\end{array}$ & & OrttSS & OrttSS & Ort $=S S$ & OrttSS & OrttSS & OrttsS & Ort $\pm S S$ & OrteSS & OrttSS \\
\hline $\begin{array}{l}\text { Evet } \\
\text { Hayru } \\
t= \\
p=\end{array}$ & $\begin{array}{l}24 \\
544\end{array}$ & $\begin{array}{c}35,120 \pm 7,279 \\
\mathbf{4 3 , 9 0 0 \pm 7 , 1 7 4} \\
-5,859 \\
0,000\end{array}$ & $\begin{array}{c}\mathbf{5 , 4 2 0 \pm 1 , 6 9 2} \\
5,370 \pm 2,148 \\
0,098 \\
0,922\end{array}$ & $\begin{array}{c}6,540 \pm 1,444 \\
7,260 \pm 1,961 \\
-1,775 \\
0,076\end{array}$ & $\begin{array}{c}5,830 \pm 2,200 \\
6,400 \pm 1,560 \\
-1,716 \\
0,222\end{array}$ & 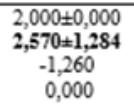 & $\begin{array}{c}7,880 \pm 1,849 \\
8,450 \pm 2,056 \\
-1,347 \\
0,178\end{array}$ & 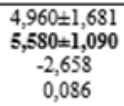 & $\begin{array}{c}5,670 \pm 1,606 \\
7,600 \pm 2,235 \\
-4,199 \\
0,000\end{array}$ & $\begin{array}{c}6,920 \pm 1,176 \\
6,220 \pm 2,039 \\
1,650 \\
0,011\end{array}$ \\
\hline $\begin{array}{l}\text { Kesilme } \\
\text { Evet } \\
\text { Hayr } \\
t= \\
p=\end{array}$ & $\begin{array}{c}65 \\
503\end{array}$ & $\begin{array}{c}\text { Ort } \pm S S \\
40,180 \pm 8,267 \\
43,960 \pm 7,161 \\
-3,925 \\
0,001\end{array}$ & $\begin{array}{c}\text { OrttSS } \\
5,140 \pm 2,098 \\
\mathbf{5 , 4 1 0 \pm 2 , 1 3 4} \\
-0,952 \\
0,342\end{array}$ & $\begin{array}{c}\text { OrttSS } \\
6,770 \pm 1,487 \\
7,290 \pm 1,992 \\
-2,036 \\
0,013\end{array}$ & $\begin{array}{c}\text { Ort } \pm \text { SS } \\
5,820 \pm 1,793 \\
\mathbf{6 , 4 5 0 \pm 1 , 5 5 3} \\
-3,050 \\
0,008\end{array}$ & $\begin{array}{c}\text { Ort+SS } \\
3,270 \pm 1,033 \\
2,530 \pm 1,275 \\
2,202 \\
0,017\end{array}$ & $\begin{array}{c}\text { Ort } \pm S S \\
8,920 \pm 1,642 \\
8,360 \pm 2,089 \\
2,084 \\
0,014\end{array}$ & $\begin{array}{c}\text { Ott } \pm S S \\
5,200 \pm 1,523 \\
\mathbf{5 , 6 0 0 \pm 1 , 0 5 7} \\
-2,700 \\
0,044\end{array}$ & $\begin{array}{c}\text { OrtsS } \\
6,450 \pm 2,916 \\
7,660 \pm 2,107 \\
-4,168 \\
0,002\end{array}$ & $\begin{array}{c}\text { OrttsS } \\
5,660 \pm 1,689 \\
6,330 \pm 2,042 \\
-2,529 \\
0,012\end{array}$ \\
\hline $\begin{array}{l}\text { Vurma } \\
\text { Evet } \\
\text { Hayur } \\
t= \\
p=\end{array}$ & $\begin{array}{l}330 \\
238\end{array}$ & $\begin{array}{c}\text { OrttSS } \\
42,740 \pm 7,386 \\
\mathbf{4 4 , 6 2 0 \pm 7 , 2 6 1} \\
-3,023 \\
0,003\end{array}$ & $\begin{array}{c}\text { OrttSS } \\
4,900 \pm 2,048 \\
6,040 \pm 2,065 \\
-6,527 \\
0,000\end{array}$ & $\begin{array}{c}\text { OrteSS } \\
6,890 \pm 1,711 \\
7,700 \pm 2,151 \\
-4,953 \\
0,000\end{array}$ & $\begin{array}{c}\text { Ort } \pm S S \\
6,090 \pm 1,705 \\
6,780 \pm 1,326 \\
-5,237 \\
0,000\end{array}$ & $\begin{array}{c}\text { OrtaSS } \\
2,490 \pm 1,125 \\
2,660 \pm 1,449 \\
-1,331 \\
0,201\end{array}$ & $\begin{array}{c}\text { OrttsS } \\
8,100 \pm 2,333 \\
8,880 \pm 1,459 \\
-4,586 \\
0,000\end{array}$ & $\begin{array}{c}\text { Ort } \pm S S \\
5,470 \pm 1,198 \\
\mathbf{5 , 6 7 0 \pm 1 , 0 0 7} \\
-2,155 \\
0,027\end{array}$ & $\begin{array}{c}\text { OrteSS } \\
7,320 \pm 2,246 \\
7,810 \pm 2,217 \\
-2,572 \\
0,010\end{array}$ & $\begin{array}{c}\text { OrtaSS } \\
6,260 \pm 1,874 \\
6,250 \pm 2,199 \\
0,056 \\
0,955\end{array}$ \\
\hline $\begin{array}{l}\text { Kurk C.lak } \\
\text { Evet } \\
\text { Hayur } \\
t= \\
p=\end{array}$ & $\begin{array}{l}145 \\
423\end{array}$ & $\begin{array}{c}\text { Ort } \pm S S \\
40,900 \pm 6,866 \\
44,430 \pm 7,351 \\
-5,062 \\
0,000\end{array}$ & $\begin{array}{c}\text { OrttSS } \\
4,950 \pm 2,015 \\
\mathbf{5 , 5 2 0 \pm 2 , 1 5 0} \\
-2,790 \\
0,005\end{array}$ & $\begin{array}{c}\text { Ort } \pm S S \\
7,030 \pm 1,467 \\
7,300 \pm 2,083 \\
-1,457 \\
0,086\end{array}$ & $\begin{array}{c}\text { Ort } \pm \text { SS } \\
6,460 \pm 1,607 \\
6,350 \pm 1,590 \\
0,731 \\
0,465\end{array}$ & $\begin{array}{c}\text { Ort } \pm S S \\
2,400 \pm 0,801 \\
2,610 \pm 1,372 \\
-1,323 \\
0,079\end{array}$ & $\begin{array}{c}\text { Ort } \pm S S \\
7,650 \pm 2,317 \\
8,690 \pm 1,879 \\
-5,428 \\
0,000\end{array}$ & $\begin{array}{c}\text { Ort } \pm \text { SS } \\
5,360 \pm 1,165 \\
\mathbf{5 , 6 2 0 \pm 1 , 1 0 5} \\
-2,418 \\
0,019\end{array}$ & $\begin{array}{c}\text { Ort } \pm \text { SS } \\
7,450 \pm 2,327 \\
7,550 \pm 2,218 \\
-0,463 \\
0,643\end{array}$ & $\begin{array}{c}\text { OrttSS } \\
6,460 \pm 1,658 \\
6,180 \pm 2,120 \\
1,446 \\
0,105\end{array}$ \\
\hline $\begin{array}{l}\text { Elektrik } \\
\text { Carpması }\end{array}$ & & OrttSS & OrttSS & OrteSS & OrttSS & OrttSS & OrttSS & OrttSS & OrtESS & OrttSS \\
\hline $\begin{array}{l}\text { Evet } \\
\text { Hayru } \\
t= \\
p=\end{array}$ & $\begin{array}{c}8 \\
560\end{array}$ & $\begin{array}{c}28,250 \pm 1,035 \\
\mathbf{4 3 , 7 4 0 \pm 7 , 2 0 7} \\
-6,075 \\
0,000 \\
\end{array}$ & $\begin{array}{c}5,120 \pm 1,553 \\
\mathbf{5 , 3 8 0 \pm 2 , 1 3 7} \\
-0,334 \\
0,738 \\
\end{array}$ & $\begin{array}{c}7,620 \pm 0,518 \\
7,230 \pm 1,959 \\
0,577 \\
0,074\end{array}$ & $\begin{array}{c}6,500 \pm 2,070 \\
6,380 \pm 1,588 \\
0,217 \\
0,828 \\
\end{array}$ & $\begin{array}{c}0,000 \pm 0,000 \\
\mathbf{2 , 5 6 0 \pm 1 , 2 7 3} \\
1,669 \\
0,000\end{array}$ & $\begin{array}{c}9,620 \pm 0,518 \\
8,410 \pm 2,058 \\
-1,718 \\
0,252 \\
\end{array}$ & $\begin{array}{c}4,880 \pm 1,553 \\
\mathbf{5 , 5 6 0} \pm 1,117 \\
-3,065 \\
0,002\end{array}$ & $\begin{array}{c}5,120 \pm 1,553 \\
\mathbf{7 , 5 6 0 \pm 2 , 2 3 6} \\
-0,888 \\
0,010\end{array}$ & $\begin{array}{c}\mathbf{5 , 6 2 0} \pm 0, \mathbf{5 1 8} \\
6,260 \pm 2,027 \\
0,000 \\
0,000\end{array}$ \\
\hline
\end{tabular}

\section{Şekil 1 (Devamı). Güvenlik Önlemlerinin Geçirilen Kaza Türlerine Göre Karşılaştırılması}

Araştırma grubunda bulunan okullarda kazalar, okul binası dişında okul bahçesinde, bina içerisinde ise merdivenlerde ve sınıflarda meydana gelmektedir. Erarslan'm çalışmasında kazaların \%28'inin sınıflarda, \%15,7'sinin okul bahçesinde, \%6,7'sinin merdivenlerde olduğu belirtilmiştir. Ergüder'in araştırmasında ise öğrencilerin kazalara en fazla okul bahçesinde $(\% 59,3)$, daha sonra siniflarda (\%26) ve merdivende $(\% 14,9)$ maruz kaldıkları bildirilmiştir. Güner kazaların en çok sınıfta $(\% 33,3)$ ikinci olarak da bahçede $(\% 30,1)$ meydana geldiğini belirtmiştir. ${ }^{16^{-18}}$

Ergüder ve Yertutan'ın çalışmasına göre çocukların okuldaki uğradıkları kazalara insan 
ve çevre faktörleri etki etmektedir. Altuntaş ve arkadaşlarının çalışmasında kronik hastalıklar, anne-baba eğitim düzeyi, okul çalışanlarının okul kazalarına yönelik bilgi ve tutumu, çocuğun başarısızlığı, sosyal sorunlar okul kazalarının meydana gelmesinde etkili çevresel faktörler olarak belirtilmiştir. ${ }^{18,}{ }^{19}$

Göze'nin kaza sıklığının saptanmasına yönelik çalışmasında; okul ortamında meydana gelen kazalar öğrencilerin okulda gün boyu yaptıkları aktivitelerden, gözlenebilen davranışlardan oluşmaktadır. $\mathrm{Bu}$ davranışların sonucundaki risklerin tanınması ile uygun kaza önleme stratejileri sağlanabilir. $\mathrm{Bu}$ amaçla, kaza açısından risk altında olan öğrencilerin güvenlik önlemleri konusundaki bilgilerinin saptanması gerekmektedir. Öğrencilerin okul içi ve çevresinde meydana gelebilecek kaza risklerini bilmeleri, kazalara karşı alınması gereken önlemler açısından önemlidir. ${ }^{19^{-21}}$

Örneklem grubunda yer alan okulların bahçesinde meydana gelen kazaların çocukların yoğun derslerden sonra dışarı çıkmaları, bahçede oynanan oyunların kuralsız-plansız, oyun alanlarının yetersiz olması, bahçede inşaat veya onarım çalışmalarının olmasından kaynaklandığ düşünülmektedir. ${ }^{22}$

Araştırmamızda okul kazalarının bahçeden sonra en çok merdiven ve sinıflarda görüldüğü belirlenmiştir. $\mathrm{Bu}$ durumun, ülkemizde okul binalarının uygun standartlarda yapilmamasindan, koridor ve siniflarda tehlike yaratan araç/gereçlerin bulunmasindan, merdivenlerin/zeminin uygunsuzluğundan ve çocuklar tarafindan bu alanların oyun alanı olarak kullanılmasından kaynaklanabilir.

Araştırma sonuçlarına göre, devlet okullarında çalışanlar özel okullarda çalışanlara göre kendi okullarında alınan genel güvenlik önlemlerinin (merdiven/koridor, spor salonu, sinıf, okul bahçesi, yakın çevredeki riskler vb.) daha yetersiz olduğunu düşünmektedirler. $\mathrm{Bu}$ sonuç Dönmez' in yaptığı araştırma sonuçları ile benzerlik göstermektedir. ${ }^{23}$

\section{SONUÇ VE ÖNERILLER}

Araştırma sonucumuzda örneklem grubunda bulunan okulların genel ve spesifik alanlarında alınan güvenlik önlemleri ile okullarda görülen kazalar arasında anlamlı ilişki bulunmuştur.

Araştırma kapsamında yer alan özel okullarda devlet okullarına göre daha fazla güvenlik önlemlerinin alındığı, okulların tümünde çocukların en çok düşme kazası geçirdikleri, kazaların en çok görüldüğü yerin okul bahçesi olduğu, kazaların genelde çocuğun kendisinden kaynaklandığı saptanmıştır.

Bu sonuçlar doğrultusunda; okulun fiziksel yapısı çocukların yaş gruplarına göre düzenlenmeli, MEB tarafindan okullar denetlenmeli ve kontrol mekanizmaları oluşturulmalı, üniversite MEB ile iş birliği yapılarak tüm okullarda kazaları önlemeye yönelik standart geliştirme çalışmaları yapilmalidir.

Okul güvenliğine ilişkin önleyici programlar öğrenci yaş grubu dikkate alınarak belirlenmelidir. Öğretmen, öğrenci ve diğer çalışanlar okul güvenliğine ilişkin eğitilmeli ve desteklenmeli, tüm okullarda revir olmalı, tam zamanlı kadrolu çalışan hemşire bulundurulmalıdır. Ayrica tüm okul çalışanlarına ilk yardım eğitimi verilmesi önerilmektedir. 


\section{KAYNAKLAR}

1. Erkal, S. ve Yertutan, C. (2012). "Çocukların Okulda Kaza Geçirme Durumu ve Okulda Kaza Geçirmelerini Önlemeye Yönelik Ebeveyn Davranıșlarının İncelenmesi". http://www.sdergi.hacettepe.edu.tr/sibelerkalcananyertutan

2. Diken, H. ve Sucuoğlu B. (1999). "Sınıfında Zihin Engelli Çocuk Bulunan ve Bulunmayan Sınıf Öğretmenlerinin Zihin Engelli Çocukların Kaynaştırılmasına Yönelik Tutumlarının Karşılaştırılması". Ankara Üniversitesi Eğitim Bilimleri Fakültesi Özel Eğitim Dergisi, 2 (03), 25-39.

3. Barhan, A. (2001). İlköğretim Okullarında Öğrenci Güvenliğinin Sağlanması. Sosyal Bilimler Enstitüsü Yüksek Lisans Tezi, Ankara Üniversitesi, Ankara.

4. Dirican, R. ve Bilgel N. (1993). Hekimliğin Tarihsel Gelişimi ve Toplum Hekimliği. Bursa: Uludağ Üniversitesi Basımevi. s.13-41.

5. Miller, T.R, Danseco, E.R. and Spicer, RS. (2000). "Incidence and Costs of 1987-1994 Childhood İnjuries". Demographic Breakdowns. Pediatrics, 105 (2), 25-27.

6. Yılmaz Kurt, F. ve Aytekin A. (2015). "0-6 Yaş Grubu Çocuklarda Ev Kazaları”. Sağlık Bilimleri ve Meslekleri Dergisi, 2 (1), 22-32.

7. Laflamme, L, Svanström, L. and Schelp, L. (2000). Safety Promotion Research. Karoliska Instituet Deperment of Public Health Sciences. Division of Social Medicine. ISBN 91-6307856-2. Sweden.

8. Türkiye İstatistik Kurumu. (2014). İstatistiklerle Çocuk. Ankara. 56-95.

9. Türkiye İstatistik Kurumu. (2017). http://www.tuik.gov.tr "' Çocuk Ölümleri', (Erişim tarihi: 03.06.2018).

10. Eraslan, R. Ve Aycan S. (2008). "Bir İlköğretim Okulu İkinci Kademe Öğrencilerinde Okul Kazası Görülme Sıklığının İncelenmesi”. Türkiye Çocuk Hastalıkları Dergisi, 2 (1), 8-18.

11. Scala, C, Gallagher, S.S. and Schneps, S. (1997). "Cause and Outcomes of Pediartic İnjry Occurring at School”. J. School Health, 67 (9),384-389.
12. Latif, A.H.A, Williams, W.R. and Sibert, J. (2002). " Primary School Accident Reporting in One Education Authority". Archives of Disease in Childhood, 86 (2), 91.

13. Vosskuhler, M. (2005). Brining The Ends Together: Learnining, Unintentional Injury\&Violence Prevention, Productivity and Academic. Performance Occupational Safety and Health Council. 12 International Safe Communities Meeting. Hong Kong, 96-106.

14. UNICEF. (2011). Türkiye'de Çocukların Durumu Raporu. UNICEF. Ankara, s.65-123.

15. Pişkin, M, Öğülmüş, S. ve Boysan, M. (2016). Güvenli Okul Ortamı Olușturma Öğretmen ve Yönetici Kitabı.

16. Güner, T. (2016). "Okul Kazalarının (Yaralanmalarının) Sosyal Güvenlik Boyutu”. Akademik Sosyal Araștırmalar Dergisi, 4 (32), 391-412

17. Ergüder, B. ve Yertutan, C. (2005). İlköğretim Okullarında Öğrencilerin Uğradıkları Kazaların İncelenmesi. HÜ Ev Ekonomisi YO Yayınları, s.39-45.

18. Altuntas, M, Kaya M, Demir, S, Oyman, G, Metecan, A. Rastgel, H. ve Öngel, K. (2013). "0-14 Yaş Arası Çocuklarda Önlenebilir Nitelikteki Kazaların Belirlenmesi ve İlişkili Tedbirlerin Alınması". Smyrna Tıp Dergisi, 1,28-33.

19. Göze, F. (2003). Bandırma Kemal Pireci Lisesi Öğrencilerinde Kaza Sıklığının Saptanması. Sağlık Bilimleri Enstitüsü Yüksek Lisans Tezi, Gazi Üniversitesi, Ankara.

20. Çalık, T, Kurt, T. ve Çalık, C. (2011). "School Climate in Creating Safe School: A Conceptual Analysis”. Pegem Eğitim ve Öğretim Dergisi, 1 (4), 73-84.

21. Özer, A. ve Dönmez, S. (2016). "Okullarda Şiddet ve Agresif Davranışların İncelenmesi”. Millî Eğitim Dergisi, 173, 67-76.

22. Alver, E, Adıgüzel, T. ve Öztürk, O. (2016). "İstanbul'da 11 Ayrı Okul Çeşidinde Okul Güvenliği Araştırması". International Journal of Eurasia Social Sciences, 7 (23), 274298

23. Dönmez, B. (2011). "Okul Güvenliği: Sorunu ve Oku Yöneticisinin Rolü’. Kuram ve Uygulamada Eğitim Yönetimi Dergisi, 7 (1), 63-74. 